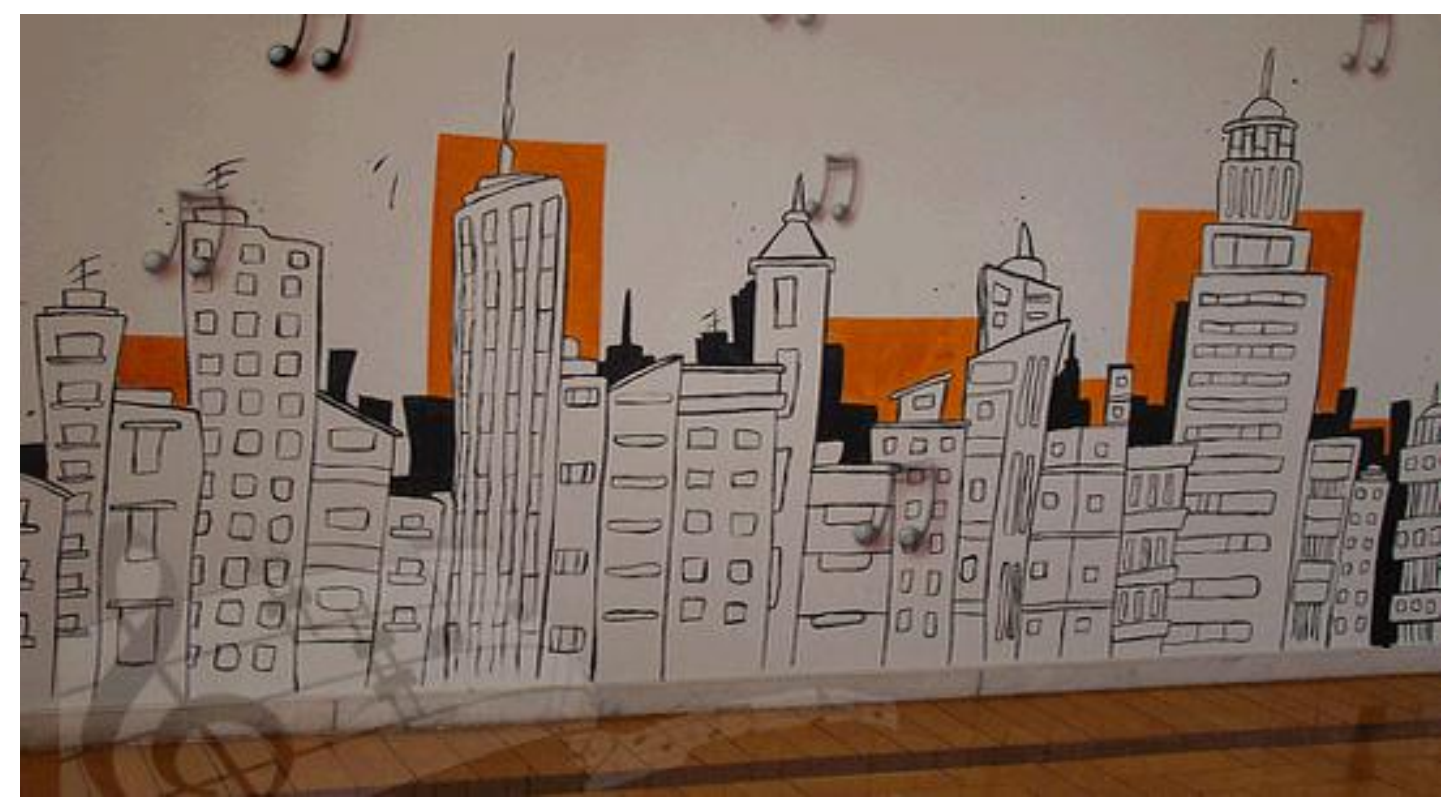

\title{
Para além do "sempre igual": cotidiano e encenação urbana no repertório de Chico Buarque
}

(Beyond the routine: daily life and urban mise en scène in the Chico Buarque's repertoire)

Flávia de Souza Fontineles*

\section{Resumo:}

Este ensaio apresenta reflexões a respeito do cotidiano urbano, a partir da leitura do par "cidade e expressão musical", numa tentativa de identificar e compreender elementos das cenas urbanas que aparecem e se articulam como cenário, tema e inspiração para canções que compõem o repertório de um dos mais conhecidos compositores brasileiros: Chico Buarque de Holanda.

Palavras-chave: cidade; cotidiano; música; Chico Buarque.

\begin{abstract}
:
This essay presents reflections about the urban daily life, extracted from the reading of the pair "city and musical expression". It is a tentative of identify and understand elements of the urban scenes which constitute sceneries, themes and inspiration for the songs of Chico Buarque de Holanda, one of the most famous brazilian composers.

Keywords: city; daily life; music; Chico Buarque.
\end{abstract}

\footnotetext{
* Mestranda do Programa de Pós-Graduação em Educação da Universidade de Brasília, filiada à Área de Concentração Educação e Comunicação. Atua como pesquisadora do Grupo de Pesquisa Lattes/CNPq "Educação Hipertextual nas produções culturais e práticas sociais". Endereço postal: SHCES 909 Bl. A, apt. 201. Cruzeiro Novo/DF. CEP: 70655-091. Endereço eletrônico: fontineles@ gmail.com
} 
Nunca dês um nome a um rio:

$\mathrm{Na}$ esteira de inquietações que têm fomentado os estudos sobre a cidade, preocupações com suas dimensões sócio-histórica e cultural têm ganhado força e notoriedade. A cidade, então, é lida como espaço urbano, animado pelas práticas cotidianas das pessoas que habitam o cenário citadino. No dizer de Bresciani (1996, p. 38), "cultura contemporânea e cidade formam duas entidades mutuamente implicadas".

Assim, os estudos sobre a cidade realizados sob essa perspectiva têm multiplicado suas lentes a fim de dedicarem atenção aos mais variados elementos e combinações de elementos que compõem as configurações complexas do espaço urbano. Estudos, desenvolvidos especialmente na área da análise do discurso, têm apontado para uma noção de cidade como espaço peculiar de interpretação, o que nos permite perguntar, conforme sugere Eni Orlandi em sua Cidade dos Sentidos (2004): "como os sujeitos interpretam a cidade, como eles se interpretam na cidade, como a cidade impõe gestos de interpretação, como a interpretação habita a cidade etc" (p.21). Um caminho possível para a investigação dessas questões parece ser dedicar atenção à vida cotidiana - um "setor privilegiado da prática" (LEFEBVRE, 1972, p.86) que institui os espaços urbanos tais como se nos apresentam.

As cidades, portanto, não aparecem descoladas da figura do urbanita, que compõe o espaço citadino tanto com sua presença e agência física como com suas experiências psicológicas, sensíveis e imaginárias engendradas nessa ambiência urbana. O reconhecimento dessa dupla, ou melhor, múltipla atuação do urbanita na configuração do espaço da cidade abre, aos pesquisadores sociais em geral, caminhos de investigação trilhados a partir da atenção dispensada às diferentes modalizações do cotidiano nas cidades.

Observando essas modalizações, muitos pares exploratórios podem ser pensados de modo a aproximar os moldes do recorte feito pelo pesquisador às formas de articulações forjadas no cotidiano urbano. Nesse esforço de compreensão, escolhi me dedicar, neste texto, a uma leitura do par cidade e expressão musical, entre os tantos entrecruzamentos possíveis. 
Sob a perspectiva da História Cultural, repertórios musicais são tomados como produtos culturais que desafiam as tentativas interpretativas por se configurarem em discursos que permeiam o cotidiano ao mesmo tempo em que o tematizam. Assim, pretendo construir, neste texto, um percurso de compreensão e exploração de referências ao cotidiano e à encenação urbana no cancioneiro de Chico Buarque.

À semelhança do que observou Negrão de Mello (1997) na obra de Adoniran Barbosa, a cidade aparece no cancioneiro de Chico Buarque não apenas como um cenário para os enredos de suas canções. Mais do que isso, o cotidiano citadino apresenta-se, muitas vezes, na obra desse compositor como o próprio enredo de seus relatos cantados, ou ainda como uma de suas “condições de produção" (Ibidem, p.150).

Temáticas atinentes ao cotidiano na cidade permeiam o repertório de Chico Buarque e compõem muito mais versos que o célebre (já referenciado no título) "todo dia ela faz tudo sempre igual", diversas vezes repetido ao longo da canção "Cotidiano" (1971). O interesse desse compositor pelo cotidiano citadino revela-se não tanto pelo fato de ter batizado um de seus discos com o nome "Cidades" quanto pela frequência com que nos deparamos com relatos cantados desse cotidiano em sua obra, a cada feita sob um viés diferenciado.

Assim, o cotidiano urbano na obra de Chico Buarque aparece centuplicado pelo relato das mais diferenciadas práticas que o compõem. Diante desse cotidiano que se mostra como quase inapreensível, espargido e impregnado em cada canto do cenário citadino, um entendimento precípuo nos socorre:

Donde sorprender la cotidianidad? Contestaremos esta pregunta de manera también aparentemente ambígua: La sorprendemos en todas partes y en niguna. No consiste ni en la vida familiar con su entorno y relaciones, ni en las distracciones, el ocio y sus actividades múltiples. Y, al mismo tiempo, es todo esto, la vida del ser humano que va de lo uno a lo outro, que se realiza y pierde tanto en el trabajo como en la família o el ocio. (LEFEBVRE, 1972, p.88)

Interessa-nos o repertório de Chico Buarque por apresentar, como condições de produção e objetos de tematizações, diversas situações cotidianas que, como recorda Teixeira (1990, p. 110), Maffesoli chamaria de "espuma dos dias". O compositor demonstra uma postura mental atenciosa - radicalmente diferente da atitude blasée descrita por Simmel (1976) - no que diz respeito ao cotidiano das cidades.

Embora tenha optado, conforme orienta Orlandi (2004), por realizar, nesse trabalho, uma análise em certo sentido despretensiosa no que diz respeito à descrição ou 
interpretação pragmática da intencionalidade do autor dos discursos em apreço, essa sensibilidade aos temas afetos ao cotidiano citadino, revelada na obra de Chico Buarque, parece tornar possível e frutífero tomar esse compositor como um entre aqueles que Negrão de Mello, tomando o referencial da Análise do Discurso, chama de "sujeitos-suportes das falas das cidades" (1997, p.151). Nesse sentido, há, na própria obra, explicitado, o reclame por dar voz aos discursos da cidade, como na canção "Subúrbio" (2006): "Fala, Penha / Fala, Irajá / Fala, Olaria / Fala, Acari, Vigário Geral / Fala, Piedade / Casas sem cor / Ruas de pó, cidade / que não se pinta / que é sem vaidade".

Nas falas da cidade, transmutadas em versos, elementos do cotidiano revelam-se em tematizações sobre aspectos corriqueiros que compõem “esses 'pequenos nadas' da vida que constituem de fato o qualitativo" (MAFFESOLI apud TEIXEIRA, 1990, p. 103). Os "pequenos nadas" são, entre outras coisas, os sons da cidade que mesmo de nossas casas somos instados a escutar.

De madrugada a gente ainda se ama

E a fábrica começa a buzinar

O trânsito contorna a nossa cama, reclama

Do nosso eterno espreguiçar (Samba e amor - 1969)

Aliás, essa mesma canção traz, de outra parte, certa indisposição ao cumprimento das exigências que o cotidiano urbano nos apresenta. Entretanto, essa aparente resistência à dinâmica cotidiana não é nada senão parte da cotidianidade, pois, como nos recorda Zaccur (2003, p. 179), "nada mais cotidiano do que assumir a vida a cada dia com maior ou menor fadiga, com maior ou menor desejo".

O compasso acelerado do cotidiano das metrópoles e a relação conflituosa do urbanita com esse tempo que se mostra exíguo, frente ao sem-número de compromissos a comparecer e deveres a cumprir, também figuram em versos que expressam nas palavras e na cadência dos sons a celeridade do tempo na metrópole.

Tenho um peito de lata

E um nó de gravata

No coração

Tenho uma vida sensata

Sem emoção

Tenho uma pressa danada

Não paro pra nada

Não presto atenção

(Cara a cara - 1969) 
O amor malfeito depressa, fazer a barba e partir

Pelo domingo que é lindo, novela, missa e gibi

(Deus lhe pague - 1971)

Talvez mais que a velocidade desse tempo, os versos acima transcritos e os demais que compõem as duas canções citadas e ainda outras, suas irmãs de sentido, expressem a necessidade de dar cumprimento ao que Maffesoli (apud TEIXEIRA, 1990) reconhece como o critério do "dever-ser" ou daquilo que orienta, na direção de uma moralidade focada numa finalidade pragmática última, as ações cotidianas dos sujeitos, de acordo com esse sentimento de dever que tende a sobrepujar, em muitos momentos, a agência puramente impulsiva.

Não são, entretanto, apenas referências ao cotidiano das grandes cidades, metrópoles, que se mostram nas canções de Chico Buarque. Integram o repertório desse compositor, músicas como “A Banda" (1966), “A noiva da cidade” (1975/76), “Gente Humilde" (1989) e outras cujos enredos que têm, notadamente, uma ambiência urbana diferente daquela própria das metrópoles. Esses versos tratam do cotidiano de ruas estreitas margeadas por "casas simples / com cadeiras na calçada / e na fachada / escrito em cima que é um lar".

Também as relações de vigilância estabelecidas entre a vizinhança, sobretudo nas pequenas cidades e nos bairros menores, aparecem em trechos que misturam referências diretas a construções metafóricas em que elementos do cotidiano urbano, de tão pertencentes aos urbanitas, servem de imagem para a expressão das emoções.

\author{
Quando aumentar a fita \\ As línguas vão falar \\ Que a dona tem visita \\ E nunca vai casar \\ Se enroscam persianas \\ Louças se partirão \\ O amor está tocando \\ O suburbano coração \\ (Suburbano Coração - 1984) \\ Eu quero fazer silêncio \\ Um silêncio tão doente \\ Do vizinho reclamar \\ E chamar polícia e médico \\ (Agora falando sério - 1969)
}

O cotidiano infantil na cidade também é algumas vezes referenciado. Aparecem, nas canções, práticas infantis ambientadas no cenário urbano, como a invasão ao terreno do vizinho onde "todo balão caía e toda maçã nascia" (Até pensei - 1968) ou as 
brincadeiras como o "futebol de rua" ou a "guerra de pipa no céu" são lembradas na canção "Doze anos" (1977/78), em meio a outros registros de brincadeiras típicas do contexto citadino de outra época em que boa parte das crianças levava o dia "trocando figurinha / matando passarinho / colecionando minhoca / jogando muito botão / rodopiando pião / fazendo troca-troca”. Ademais, no universo de obras para o público infantil, "História de uma gata" (1977) - composição para o musical infantil "Os saltimbancos" - traz o cotidiano de uma gata na cidade, dividida entre o conforto do apartamento e o convívio "no meio da gataria pela rua".

A experiência dos habitantes da cidade se mostra no cancioneiro de Buarque, contudo, não apenas multiplicada em exemplares ou aspectos tematizados, mas também em nuanças contrastadas. Assim, o próprio aspecto rotineiro da vida cotidiana, destacado no bastante conhecido e já citado verso da canção "Cotidiano" cede lugar, em outras canções, para o rompimento com a rotina, ${ }^{1}$ ou mesmo para as ocasiões de suspensão da cotidianidade.

Essas pequenas diferenças no que experimentamos como rotineiro dizem respeito ao que Zaccur (2003), apoiada no referencial de Deleuze, aponta como iterância: "o que aparentemente se repete, no próprio processo da repetição, tanto se reitera como se recria, produz iterâncias realimentadoras" (p.180).

O cotidiano aparece na obra de Chico Buarque em suas rotinas e iterâncias, em repetições e diferenças retroalimentadoras. É nessa dinâmica da iterância que os amantes se encontram na canção Valsinha (1970):

Um dia ele chegou tão diferente do seu jeito de sempre chegar Olhou-a dum jeito muito mais quente do que sempre costumava olhar E não maldisse a vida tanto quanto era seu jeito de sempre falar E nem deixou-a só num canto, pra seu grande espanto convidou-a pra rodar

Por outra parte, o relato da viagem, em Bye Bye, Brasil (1979), revela, no intempestivo percurso do viajante, certa regularidade: "Bye bye, Brasil / A última ficha caiu / Eu penso em vocês night and day / Explica que tá tudo okay / Eu só ando dentro da lei”.

\footnotetext{
${ }^{1}$ A própria canção "Cotidiano" foi, numa de suas gravações mais conhecidas (do disco Caetano e Chico juntos e ao vivo, 1972), unida, nas vozes de Chico Buarque e Caetano Veloso, a "Você não entende nada", música de autoria do próprio Caetano que relata justamente a tensão estabelecida no cotidiano e o desejo de ver o inusitado insurgir da rotina, em versos como estes: "Você tem que saber que eu quero correr mundo/ Correr perigo/ Eu quero é ir-me embora/ Eu quero dar o fora/ e quero que você/ venha comigo/ todo dia".
} 
É este aparentemente contraditório par - diferença e repetição - que imprime ritmo ao cotidiano. Aliás, o ritmo é uma boa imagem, evocada por Maffesoli e lembrada por Zaccur (2003), para compreender a associação entre movimento e estabilidade. E é esse ritmo, essa variação naquilo que é diário, que nos permite escapar do que Benjamin, conforme recorda Rouanet (1992), classifica como a temporalidade do inferno, o tempo da repetição infinita (castigos eternos), sem diferenciação. Lembrando Lefebvre (1972, p.94): "La calle se repite y cambia como la cotidianidad: se reitera en el cambio incesante de las gentes, los aspectos, los objetos y las horas".

Assim, o cotidiano que, no senso comum, tem um sentido muito associado à repetição, é composto, em seu desenho geral, por eventos assemelhados, porém não idênticos. No dizer de Teixeira (1990),

a vida cotidiana se compõe de micro-atitudes, de criações minúsculas, de situações pontuais e totalmente efêmeras. É, stricto sensu, uma trama feita de fios minúsculos estreitamente tecidos, onde, cada um, em particular, é exatamente insignificante. Mas é exatamente essa insignificância que constitui a força e garante a permanência da vida cotidiana. A existência cotidiana é ruidosa, polissêmica, constituída de sombras e luzes, em uma palavra, é feita por um homem ao mesmo tempo 'sapiens' e 'demens'. (p.103).

A impressão de repetição experienciada no dia-a-dia, entretanto, pode justificarse pelo fato de que, na maior parte dos casos, as diferenças abrigadas sob a cotidianidade são sutis e se limitam a produzir iterâncias, como destaca Lefebvre: "el espetáculo de la calle, variable e idêntico, ofrece solo sorpresas limitadas, salvo accidentes [...] lo sensacional rompe rara vez la monotonía diversa de la calle" (1972, p.94). O extraordinário raras vezes chega a suspender o cotidiano em suas linhas gerais e essa suspensão, como mais um tema afeto à vida nas cidades, também é referenciada no cancioneiro de Chico Buarque.

\section{SUSPENSÃO DA COTIDIANIDADE}

O calendário das cidades inclui ocasiões em que a rotina não é propriamente destituída, mas é suspensa por um período determinado e não muito longo. Eventos variados podem propiciar essa suspensão momentânea, contudo, aqueles ligados à arte são particularmente propícios a essa interrupção do fluxo rotineiro do dia-a-dia. Como aponta Negrão de Mello (1998, p.193), 
[a poesia do tango] tem o dom de promover, ainda que episodicamente, uma suspensão da cotidianidade, ou seja, daquilo que é puramente rotineiro. Se suprimi-la seria impossível, pois 'nenhuma existência individual' cancela a cotidianidade, a arte, e no caso em tela, o tango, seja no âmbito da criação ou no da fruição, eixo aqui aludido, é um vetor na dialética cotidianidade-suspensão.

Na canção de Chico Buarque o desfile da banda pelas ruas da cidade é o que desencadeia a suspensão da rotina, o abandono temporário dos afazeres, das preocupações diárias e da consciência de cada lugar social ocupado, sendo toda a atenção concentrada na fruição do espetáculo dos músicos percorrendo as ruas da cidade. Entretanto, na sequiência, constata-se que "tudo tomou seu lugar / depois que a banda passou".

\author{
A minha gente sofrida \\ Despediu-se da dor \\ Pra ver a banda passar \\ Cantando coisas de amor \\ O homem sério que contava dinheiro parou \\ $\mathrm{O}$ faroleiro que contava vantagem parou \\ A namorada que contava as estrelas parou \\ Para ver, ouvir e dar passagem \\ (A Banda - 1966)
}

A suspensão da cotidianidade parece estar associada diretamente a uma suspensão da noção, supracitada, do "dever-ser" (TEIXEIRA, 1990). Em determinados momentos, esse "dever-ser", que, em última instância, motiva as ações rotineiras de manutenção da ordem estabelecida, acha-se suspendido e então a cotidianidade se interrompe, dando lugar a uma dinâmica mais associada aos sentidos, à espontaneidade ou mesmo a regras ritualísticas específicas.

Nesse sentido, as festas são ocasiões típicas de suspensão da cotidianidade. As grandes festas que ganham espaço no cotidiano citadino exigem a interrupção da trivialidade e costumam arrastar multidões às ruas da cidade em feriado. No Brasil, tem grande importância e participação um evento festivo muito associado a essa suspensão: o carnaval. Várias canções do repertório de Chico Buarque trazem a idéia do carnaval diretamente relacionada à interrupção da ordem habitual. Assim, na canção "Cordão" (1971) o apelo por um evento que abale a conformação rotineira é feito pelos versos "quero ver o vendaval / quero o ver o carnaval / sair". O carnaval aparece com muita frequência no cancioneiro de Buarque com esse mesmo sentido de interrupção da rotina. 
Em "Noite dos Mascarados" (1966), as formalidades habituais de apresentação e relacionamento entre dois pretendentes são colocadas em suspensão e o horizonte temporal é reduzido ao tempo da festividade, de modo que são abandonadas as preocupações futuras.

\author{
Mas é carnaval \\ Não me diga mais quem é você \\ Amanhã, tudo volta ao normal \\ Deixe a festa acabar \\ Deixe o barco correr \\ Deixe o dia raiar \\ Que hoje eu sou \\ Da maneira que você me quer \\ (Noite dos Mascarados - 1966)
}

Como sinaliza o verso, "amanhã tudo volta ao normal", o carnaval aparece como um momento de suspensão momentânea da cotidianidade e a quarta-feira de cinzas é um marco da volta à esfera de ação regulada pela normalidade, pelo "dever-ser". Assim, em "Ela desatinou" (1968), a moça é dada como insana porque "viu chegar quarta-feira / acabar brincadeira / bandeiras se desmanchando / e ela ainda está sambando". E é assim com toda ocasião de suspensão da cotidianidade, pois não se pode prescindir do ritmo cotidiano habitual e a ele sempre retornamos nossas ocupações rotineiras sempre as mesmas e sempre outras na dinâmica da iterância.

Como na referência feita na canção "Ano novo" (1967), alguns historiadores e sociólogos enxergam nessas ocasiões de festa uma saída de escape para o alívio da pressão criada pelo cotidiano em certo sentido opressor, sobretudo, para as classes menos favorecidas.

\footnotetext{
Há muito tempo

Que essa minha gente

Vai vivendo a muque

É o mesmo batente

É o mesmo batuque

Já ficou descrente

É sempre o mesmo truque

E quem já viu de pé

O mesmo velho ovo

Hoje fica contente

Porque é Ano Novo

(Ano Novo - 1967)
} 
No entanto, Sohiet (1998) alerta para a necessidade de pensarmos a festa em suas significações culturais, já que, por mais que possa servir como estratégia de controle social, a festividade é também uma forma de expressão cultural legítima, que pode possibilitar "ao historiador, munido do método indiciário, alcançar os significados sociais, por vezes inacessíveis por outros caminhos" (p. 25).

Assim, a respeito da popularidade das festas pertencentes ao calendário católico do Rio de Janeiro durante o Império, Sohiet (1998) aponta que "para os populares, esses festejos assumiam uma dimensão lúdica, pois neles tinham oportunidade de atender às suas necessidades de lazer, expressando de inúmeras formas seu universo cultural" (p.20).

As festas e demais ocasiões de suspensão da cotidianidade citadina, assim como a manutenção do ritmo habitual do cotidiano, dependem sobremaneira do ânimo de seus habitantes, das disposições individuais e coletiva de interromper a rotina. Sem exageros, é possível dizer que não há festa sem convivas ou foliões, assim como não há cidade sem seus habitantes, em presença física ou rememorada. Esses sujeitos, personagens da encenação urbana diária, são também cantados em versos do cancioneiro de Chico Buarque.

\section{PERSONAGENS QUE HABITAM E ANIMAM A CIDADE}

Tomado de empréstimo o verso da canção "As vitrines" (1980), vazia das práticas que a configuram e que lhe imprimem ritmo, "a cidade era um vão". As cidades, sem as práticas dos urbanitas, em presença ou em memória, são apenas lugares.

A noção de lugar, de acordo com Michel de Certeau (1994), difere substancialmente daquela referente a espaço. O lugar é apenas um conjunto de objetos em ordenação, o sentido de espaço só se dá pela animação, pelos movimentos e práticas instauradas nos lugares.

Existe espaço sempre que se tomam em conta vetores de direção, quantidades de velocidade e a variável tempo. O espaço é um cruzamento de móveis. É de certo modo animado pelo conjunto dos movimentos que aí se desdobram (Ibidem, p.202)

Assim, no entender de Certeau, "espaço é um lugar praticado". E que são as cidades, senão lugares tornados espaços pela encenação diária das pessoas comuns que animam os cenários urbanos e neles produzem suas práticas? No "teatro de ações" (Ibidem, p.209) cantado por Chico Buarque, várias pessoas habitam a cidade e seus 
personagens encenam o cotidiano citadino, animando os lugares e desenhando a fisiognomia ${ }^{2}$ dos espaços urbanos.

Gostosa / Quentinha / Tapioca / O pregão abre o dia / Hoje tem baile funk / Tem samba no Flamengo / O reverendo / No palanque lendo / O Apocalipse / O homem da Gávea criou asas / Vadia / Gaivota / Sobrevoa a tardinha / E a neblina da ganja / O povaréu sonâmbulo / Ambulando / Que nem muamba / Nas ondas do mar / Cidade maravilhosa / És minha / O poente na espinha / Das tuas montanhas / Quase arromba a retina / De quem vê / De noite / Meninas / Peitinhos de pitomba / Vendendo por Copacabana / As suas bugigangas / Suas bugigangas (Carioca - 1998)

Inspirado no cenário do Rio de Janeiro, já sabidamente "antropomorfizado" em figuras como a do malandro, conforme recorda Negrão de Mello (2003, p.15), Chico Buarque canta os personagens típicos da cena cotidiana dessa cidade na canção "Carioca" (1998). Figuram em seus versos: o vendedor de tapioca na praia; o praticante de vôos de asa delta que salta da pedra da Gávea; a gaivota; os ambulantes; e as adolescentes, meninas, prostituindo-se em troca, sobretudo do dinheiro estrangeiro, nas praias de Copacabana. Referências ao cotidiano das prostitutas e à sua encenação no cenário urbano aparecem ainda em outras canções como "Folhetim" (1978) e "Las muchachas de Copacabana" (1985).

A figura do malandro, ícone do imaginário a respeito da cidade do Rio de Janeiro, também foi evocada em diversas músicas desse repertório como, por exemplo, as duas versões de Chico Buarque para a canção de Kurt Weill e Bertold Brecht ("O malandro" e "O malandro no 2", ambas de 1977/78), "A volta do malandro" (1985) e "Homenagem ao malandro" (1977-78).

O malandro
Na dureza
Senta à mesa
Do café
Bebe um gole
De cachaça
Acha graça
E dá no pé
(O malandro - 1977/78)

Eis o malandro na praça outra vez

Caminhando na ponta dos pés

Como quem pisa nos corações

Que rolaram dos cabarés

(A volta do malandro - 1985)

\footnotetext{
${ }^{2}$ Expressão que, a exemplo de Willi Bolle (1994), empresto de Walter Benjamin. 
O cotidiano da violência, das crianças envolvidas em situações de risco, também aparece nas canções, pela voz do pai do menino assassinado em "O meu guri” (1981) ou pela notícia da mortalidade infantil em "Brejo da Cruz" (1984), ou ainda pelo cotidiano do "pivete", cantado nos versos de 1978:

No sinal fechado / Ele vende chiclete / Capricha na flanela / E se chama Pelé / Pinta na janela / Batalha algum trocado / Aponta um canivete / E até / Dobra a Carioca, olerê / Desce a Frei / Caneca, olará/ Se manda pra Tijuca / Sobe o Borel / Meio se maloca / Agita numa boca / Descola uma mutuca / E um papel / Sonha aquela mina, olerê / Prancha, parafina, olará / Dorme gente fina / Acorda pinel

(Pivete - 1978)

$\mathrm{Na}$ canção "A cidade dos artistas" (1981), composta para o filme "Os Saltimbancos Trapalhões" ${ }^{3}$, o cotidiano dos artistas de rua é colocado em destaque, pela voz dos próprios atores.

Na cidade / Ser artista / É subir na cadeira / Engolindo peixeira / É empolgar o turista / É beber formicida / É cuspir labareda / É olhar a praça lotando / E o chapéu estufando / De tanta moeda / É cair de joelhos / É dar graças ao céu / Lá se foi o turista / O dinheiro, a peixeira / A cadeira e o chapéu (A cidade dos artistas - 1981)

Também a encenação diária dos trabalhadores é objeto de canções como "Pedro Pedreiro" (1965) e "Construção" (1971), desde o amanhecer, quando estão nos terminais "esperando o trem", até o trabalho de erguer paredes, "tijolo por tijolo, num desenho lógico".

Outros tantos personagens, encenados pelo que Silva chamará de "pessoas comuns" (1996, p.94) que animam os cenários urbanos ou, no dizer de Certeau (1994), "praticam os lugares", criando os espaços citadinos, são evocados na música de Chico Buarque.

Todavia, não apenas o espaço urbano se constitui pela encenação interativa dos personagens que o habitam, mas também as pessoas se constituem nesse jogo de cenas. Maffesoli, como nos recorda Teixeira (1990), considera adequado recorrer à etimologia da palavra pessoa (persona - máscara) para compreender que a entidade "eu"

\footnotetext{
${ }^{3}$ Filme dirigido por JB Tanko e lançado em 1981.
} 
pode ser mutável e se integra numa variedade de cenas e de situações, válidas somente porque representadas em conjunto. À multiplicidade do eu corresponde uma ambiência comunitária, porque, ao contrário da noção de indivíduo que se apóia numa lógica de identidade isolada, a pessoa só existe na relação com o outro, portanto enquanto participante de uma comunidade (p.136).

Se, de um lado, "sim, os homens habitam as cidades enquanto objeto real. Nesse nível, ela é uma entidade concreta, com suas ruas, praças e sistemas de transporte" (ROUANET e PEIXOTO, 1992, p. 71), esses meios de transporte bem podem ser como chamam os gregos, methaphorai ${ }^{4}$ e os homens que se movem pelo espaço urbano também cavalgando seus relatos, têm seu imaginário habitado pela cidade.

\section{CIDADES QUE HABITAM HOMENS}

Em resposta à pergunta sobre as cidades habitarem os homens ou os homens nela residirem, Rouanet arrisca uma resposta que julga ser a de Walter Benjamin:

Ele responderia que o homem habita uma cidade real e é habitado por uma cidade de sonho. Essa dualidade resume o essencial do Trabalho das Passagens. Em todos os momentos, Benjamin joga com dois níveis de realidade, a realidade objetiva e a onírica. (ROUANET e PEIXOTO, 1992, p.67)

Essa imagem da cidade que habita os homens aparece assim mesmo num verso da canção "Assentamento" (1997) que dá voz a um personagem migrante do sertão para cidade, que, hoje saudoso da "campina quando flora" e resolvido a ir embora, convoca seus pares a segui-lo, dizendo "a cidade não mora mais em mim / Francisco, Serafim / Vamos embora".

Rouanet prossegue com a resposta à pergunta lançada, ainda apoiado no referencial de Benjamin, sugerindo que "é nos homens que a cidade mora, porque é parte de sua vida de sonho" (1992, p.71). A cidade, portanto, não só habita os homens, como é objeto de suas idealizações.

Entre as canções que compõem o musical infantil "Os Saltimbancos” (1977) está “Cidade Ideal”, cuja letra se refere à expectativa, às idealizações que cada bicho (antropomorfizado) faz a respeito da cidade que se aproxima. As idealizações da cidade

\footnotetext{
4 "Na Atenas contemporânea, os transportes coletivos se chamam methaphorai. Para ir para o trabalho ou voltar para casa, toma-se uma 'metáfora' - um ônibus ou um trem." (CERTEAU, 1994, p. 199).

${ }^{5} \mathrm{O}$ musical de Enriquez e Bardotti narra a aventura de um grupo de bichos que se conhecem no caminho de migração para a cidade.
} 
trazem uma combinação dos elementos exteriores já conhecidos dos bichos, reorganizados segundo os desejos de cada animal.

\author{
Cachorro: A cidade ideal dum cachorro \\ Tem um poste por metro quadrado \\ Não tem carro, não corro, não morro \\ E também nunca fico apertado \\ Galinha: A cidade ideal da galinha \\ Tem as ruas cheias de minhoca \\ A barriga fica tão quentinha \\ Que transforma o milho em pipoca \\ (Cidade ideal - 1977)
}

Além de se tornar objeto de idealizações dos sujeitos, a cidade parece interferir na vida psíquica de seus habitantes e, de acordo com Simmel (1976), cria "condições psicológicas" manifestas nas pequenas atitudes diárias dos sujeitos. Dessa forma, segundo Simmel (1976, p.15),

todas as exterioridades mais banais da vida estão, em última análise, ligadas às decisões concernentes ao significado e estilo de vida. Pontualidade, calculabilidade, exatidão, são introduzidas à força na vida pela complexidade e extensão da existência metropolitana e não estão apenas muito intimamente ligadas à sua economia do dinheiro e caráter intelectualístico.

Cidade e cotidiano acham-se assim imiscuídos naquilo que constitui a experiência diária do urbanita, tanto em nível de seu comportamento psicológico como de sua prática diária desde o seu despertar matinal até o desfecho da vida.

\title{
CIDADE, COTIDIANO E HISTÓRIA
}

Não é sem razão que os versos de "Cantiga de acordar" (2001), usam como imagem do absurdo a existência de um tempo sem lugar: "foi uma ilusão / uma insensatez [...] era como um trem / que anda sem passar / era um tempo / sem lugar". A existência histórica só pode ser entendida nesse entrecruzamento entre um espaço e um tempo, aliás, duas categorias fundamentais para a história.

Assim como espaço e tempo se conjugam na configuração dos acontecimentos, o espaço da cidade está impregnado de história e, como na canção "Vai passar" (1984), “cada paralelepípedo da velha cidade" é capaz de lembrar o que passou. 
Cada paralelepípedo / Da velha cidade / Essa noite / Vai se arrepiar / Ao lembrar / Que aqui passaram / sambas imortais / Que aqui sangraram / pelos nossos pés / Que aqui sambaram / nossos ancestrais

É dessa forma que, como observa Rouanet (1992), o flâneur lê, nas ruas, a história daqueles espaços e também a sua: "cada rua para ele é uma ladeira que desce em direção ao passado, o dele e o da cidade" (p.50).

Entretanto, se a cidade dá pistas da história, a história também dá pistas do espaço urbano e o faz a partir do relato das práticas que têm, na cidade, seu objeto e ambiência. Essas práticas são a substância da vida cotidiana que se presta à apreensão pela atenção às suas modalizações.

Nesse sentido, Certeau (1994) chama atenção para o fato de que "os relatos cotidianos contam aquilo que, apesar de tudo, se pode aí fabricar e fazer. São feituras de espaço" (p. 207).

Assim, os relatos do cotidiano são objetos muito afeitos ao interesse da história cultural que "tem por principal objeto identificar o modo como em diferentes lugares e momentos uma determinada realidade social é construída, pensada, dada a ler" (CHARTIER, 1990, p. 17).

Sob essa perspectiva, tomado como sujeito-suporte dos relatos citadinos, numa modalização cidade e musicalidade, Chico Buarque traz, em sua obra, muitas referências ao cotidiano das cidades, às rotinas e iterâncias próprias à nossa experiência diária no mundo.

Assim, se o crescimento desordenado da cidade aliado à especulação imobiliária fez (e ainda faz) brotar do chão um novo prédio, num piscar de olhos, em cada grande centro urbano, em "Carta ao Tom" (1977), figuram os versos "minha janela não passa de um quadrado / a gente só vê Sérgio Dourado / onde antes se via o Redentor”.

E se, por outro lado, das favelas "não sai foto nas revistas", um bom relato do cotidiano desses espaços urbanos é apresentado na canção "Subúrbio" (2006), em cujas rimas as "casas sem cor" dos bairros de "ruas de pó" ganham pintura com a expressão das práticas constitutivas de seus espaços.

No cancioneiro de Chico Buarque, em qualquer das músicas aqui referidas e ainda em outras, são encontrados não apenas referências a eventos e circunstâncias relativos ao cotidiano urbano, mas legítimos relatos, emergidos de uma espécie de memória difusa, de algumas das encenações cotidianas que, reconhecidamente, constituem as cidades. 


\section{REFERÊNCIAS BIBLIOGRÁFICAS}

BRESCIANI, M. Stella. Cultura e História, uma aproximação possível. In: PAIVA, M.; MOREIRA. M. E. (orgs.). Cultura. Substantivo Plural. Rio de Janeiro: Ed. 34. 1996. pp.35-53.

BOLLE, Willi. Fisiognomia da Metrópole Moderna. Representação da História em Walter Benjamin. São Paulo: EDUSP. 1994.

CHARTIER, Roger. A História Cultural - entre práticas e representações. Lisboa: Difel. 1990.

CERTEAU, Michel de. A invenção do cotidiano. Petrópolis/RJ: Vozes. 1994.

LEFEBVRE, H.Introducción a la psicosociologia de la vida cotidiana. In: La vida cotidiana en el mundo moderno. Madri: Editorial S/A. 1972. p. 85-102.

NEGRÃO DE MELLO, Maria T. Cascariguindum - cotidiano, cidadania e imaginário na obra de Adoniran Barbosa. In: MENEZES, Albene M. (org.). História em movimento (temas e perguntas). Brasília: Thesaurus. 1997. p. 147-160.

Porteiro suba e diga àquela ingrata - tango argentino, imaginário e cotidiano.

In: ALMEIDA, Jaime de. Caminhos de história da América no Brasil - tendências e contornos de um campo historiográfico. Brasília: Anphlac. 1998. p. 191-202.

Santa Maria, Pinta e Nina: A redescoberta dos Caribes em espaços discursivos brasileiros. In: ALMEIDA, Jaime de; CABRERA, Olga; ZAVALA, Maria T. (orgs.). Cenários Caribenhos. Brasília: Paralelo 15. 2003. p.13-31.

ORLANDI, Eni. Cidade dos sentidos. Campinas/SP: Pontes. 2004.

ROUANET, S. Paulo; PEIXOTO, N. Brissac. É a cidade que habita os homens ou eles que moram nela? In: Revista USP. Dossiê Walter Benjamin. 1992. p. 50-75.

SIMMEL, Georg. A metrópole e a vida mental. In: GUILHERME VELHO, O. $O$ fenômeno urbano. Rio de Janeiro: Zahar. 1976.

SOHIET, Rachel. A subversão pelo riso; estudos sobre o carnaval carioca da Belle Époque ao tempo de Vargas. São Paulo: FGV. 1998.

TEIXEIRA, M. Cecília Sanchez. Socio-antropologia do cotidiano: a abordagem de Michel Maffesoli. In: Antropologia, cotidiano e educação. Rio de Janeiro, Imago. 1990. p. $97-151$.

ZACCUR, Edwiges. Metodologias abertas a iterâncias, interações e errâncias cotidianas. In: GARCIA, Regina Leite (org.). Método: pesquisa com o cotidiano. Rio de Janeiro: DF\&A. 2003. p. 177-198. 
Para citar essa obra:

FONTINELES, Flávia de Souza. Para Além do "Sempre Igual": Cotidiano e Encenação Urbana no Repertório de Chico Buarque. RUA [online]. 2010, no. 16. Volume 2 - ISSN 1413-2109

Consultada no Portal Labeurb - Revista do Laboratório de Estudos Urbanos do Núcleo de Desenvolvimento da Criatividade

http://www.labeurb.unicamp.br/rua/

Laboratório de Estudos Urbanos - LABEURB

Núcleo de Desenvolvimento da Criatividade - NUDECRI

Universidade Estadual de Campinas - UNICAMP

http://www.labeurb.unicamp.br/

Endereço:

Rua Caio Graco Prado, 70

Cidade Universitária "Zeferino Vaz" - Barão Geraldo

13083-892 - Campinas-SP - Brasil

Telefone/Fax: (+55 19) 3521-7900

Contato: http://www.labeurb.unicamp.br/contato 